\title{
Express techniques for laboratory definition of reservoir permeability recovery coefficient due to the influence of fracturing fluid
}

\begin{abstract}
An express method of fracturing fluid influence estimation on the permeability of production reservoirs is offered, by using a sand-pack model heated up to reservoir temperature. A part of the model is filled with quartz sand fraction of a given permeability. The rest of the model is filled with proppant. The model is saturated with saline water and heated up to reservoir temperature. Initially, water permeability for the sand-pack model part is determined. Then, hydraulic fracturing fluid is injected in the model proppant part. During injection, recording of the filtrate volume and differential pressure changing, allows us to estimate the filterability of the fracturing fluid. After exposure time for fluid breaking, during the filtration process of saline water in the opposite direction, we can estimate destruction rate according to the obtained permeability recovery coefficient of the model part filled with sand. In this article the results of the plugging properties investigation and the impact on permeability of the porous medium before and after the gel destruction of the two fracturing fluids (crosslinked polysaccharide gel and the experimental non-guar of fracturing fluid) are shown. There are significant differences in fluid behavior during filtration through a porous medium, which depends on the mechanisms of gel systems formation. It is shown, that the recovery factor of permeability, depends on the depth of fracturing fluid penetration in a porous medium.
\end{abstract}

Key words: cross-linked polysaccharide gel, destruction, fluid, filtration, fracture, guar, per-meability, porosity, proppant, sand model.

\section{Szybkie techniki do określenia laboratoryjnego współczynnika odzysku przepuszczalności zbiornika ze względu na oddziaływanie płynu szczelinującego}

Szybka metoda oszacowania wpływu płynu szczelinującego na przepuszczalność zbiornika produkcyjnego jest oferowana poprzez zastosowanie modelu sand-pack podgrzanego do temperatury zbiornika. Część tego modelu jest wypełniona frakcją piasku kwarcowego o określonej przepuszczalności. Reszta modelu jest wypełniona podsadzką. Model ten jest nasycony solanką i ogrzany do temperatury zbiornika. Początkowo, przepuszczalność wody części modelu sand-pack jest ustalona. Następnie, płyn do szczelinowania hydraulicznego jest wtryskiwany do części modelu podsadzki. Podczas wtrysku, zapis zmiany objętości filtratu i ciśnienia różnicowego pozwala na oszacowanie filtrowalności płynu szczelinującego. Po czasie ekspozycji na zerwania płynu w trakcie procesu filtracji słonej wody w przeciwnym kierunku, można oszacować wskaźnik zniszczenia, w zależności otrzymanego współczynnika odzysku przepuszczalności tej części modelu wypełnionej piaskiem. W artykule są pokazane wyniki badania właściwości zatykania oraz wpływu na przepuszczalność porowatego nośnika przed i po zniszczeniu żelu dwóch płynów szczelinujących (usieciowanego żelu polisacharydu i eksperymentalnego non-guar płynu szczelinującego). Istnieją znaczące różnice w zachowaniu płynu podczas filtracji przez porowaty nośnik, które zależą od mechanizmów powstawania systemów żelowych. Jak widać, współczynnik odzyskiwania przepuszczalności zależy od głębokości penetracji płynu szczelinującego w porowatym nośniku.

Słowa kluczowe: sieciowany polisacharydowy żel, destrukcja, płyn, filtracja, szczelina, guar, przepuszczalność, porowatość, propant, model piaskowy.

The "Oilfield Chemistry" Experimental Researching and Education Centre (REC) for physical modeling of promising techniques of reservoir recovery enhancement, at the Gubkin
Russian State University of Oil and Gas (NRU), developed a method for comparative evaluation of the influence of fracturing fluids on permeability and porosity of produc- 
tive reservoirs and on their ability to be filtered out into the porous medium.

Among the characteristics defining the properties of a fracturing fluid and the feasibility of its application in specific reservoir conditions, namely rheological properties, rate and extent of destruction, friction loss factor, the parameter such as the efficiency of the fracturing fluid is extremely important. This parameter is the ratio of the fluid volume for creation and widening of the reservoir fracture to the total volume of a fracturing fluid injected into the formation. On the other hand, the efficiency of a fracturing fluid, the amount and composition of a filtrate and the destruction degree, determine the extent of permeability recovery in the production reservoir porous medium after hydraulic fracturing.

Permeability recovery coefficient of the porous medium is determined under laboratory conditions, during the filtration experiment, as the ratio of the water or the hydrocarbon phase permeability coefficient of a porous medium model after exposure, that is, after filtering a test composition or reagent through it, to the initial value of the permeability coefficient of the same fluid prior to the exposure. Yet it is important to understand that under laboratory conditions, the obtained permeability recovery coefficient depends on the length of the porous medium model. The greater the length of the model, the less the exposed model part and, respectively, higher the permeability recovery coefficient.

In the absence of a common standard for the selection of equipment and experimental techniques, when performing this type of experiments, the best option to obtain sound results, is performing comparative experiments. For this purpose, two or more fracturing fluids are to be tested under the same conditions. One of them is a well-known fluid commonly used for fracturing, as a comparative sample. The second one is the fluid we are investigating. After the comparative experiments, the conclusions of the fracturing fluid applicability in these geological and physical conditions are drawn on the grounds of the analysis of the results obtained.

To perform physical modeling within this method, a HP-CFS filtration unit designed in the Oilfield Chemistry REC at the Gubkin Russian State University, is used, allowing to carry out filtration experiments on sand packed models of the porous medium, and on core samples, at temperatures up to $150^{\circ} \mathrm{C}$ and pressures up to $20.0 \mathrm{MPa}$. The unit diagram is shown in Figure 1.

To perform the experiments for determining the permeability recovery coefficient of the porous medium after the influence of the liquid, thermostatically controlled packed reservoir models are used.

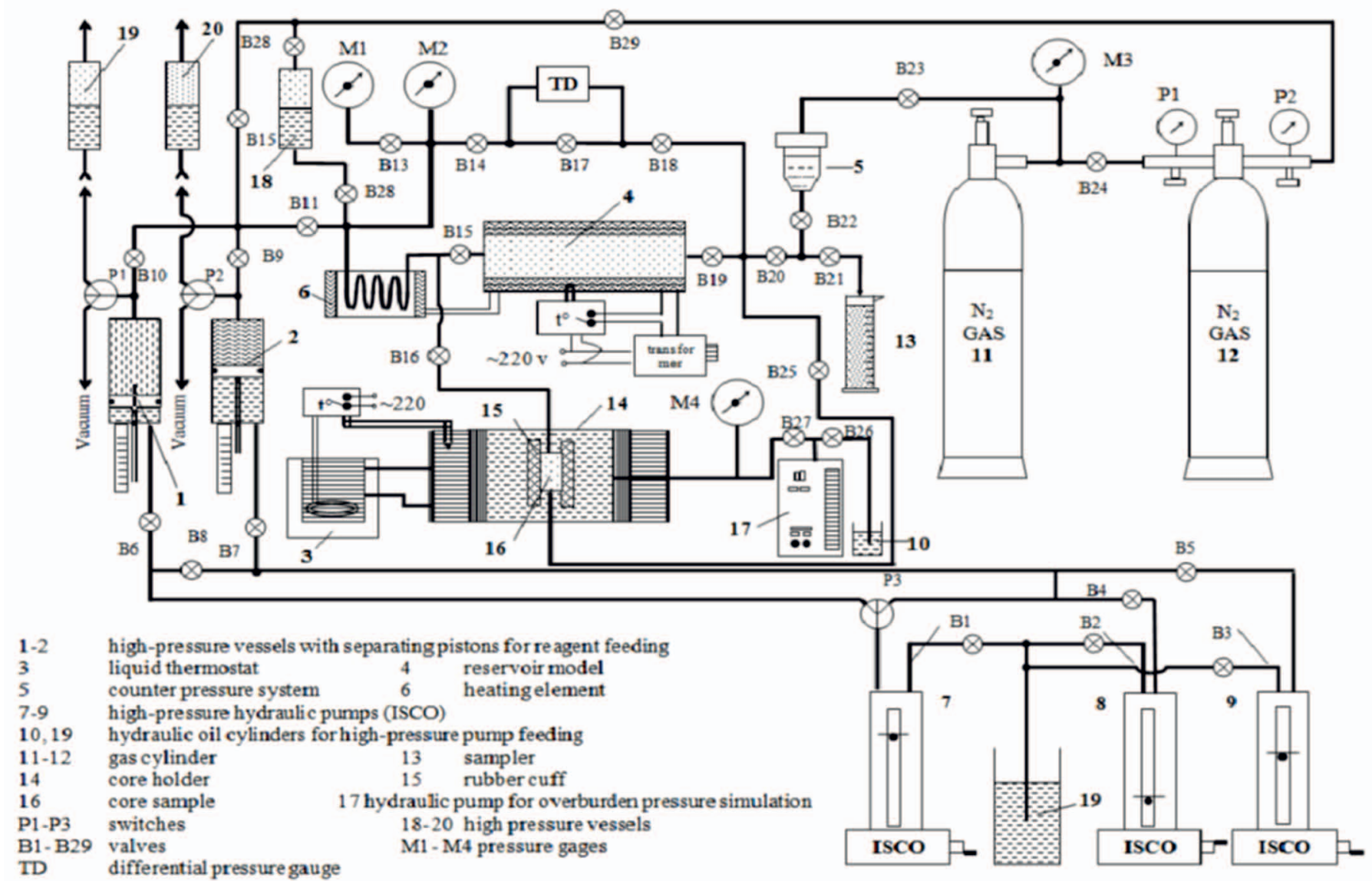

Fig. 1. Schematic diagram of the HP-CFS filtration unit 
It should be noted that the sand packed models in contrast to the real core samples, are very accessible to the carrying out of comparative experiments tests for investigating the compositions, whose impact on permeability and porosity of the porous medium is not related to the reaction of the composition with different porous medium ingredients, and to the influence of such reaction products on these properties.

The porous medium structure of the real core sample is usually complicated and individual for each sample. The porous medium structure of the packed reservoir model is regular and practically the same for each value of permeability coefficient. The same porous medium structure of packed reservoir models, along with other equal/similar conditions makes it possible to compare the results obtained.

According to the techniques, in the preparatory stage, the model part is packed with ground quartz sand fraction of a given permeability. The rest of the model is filled with proppant. In order to avoid sand getting into the proppant while filtering, a technological interlayer consisting of a number of sand fraction layers of permeability $2.5,15.0$ and $147.0 \mu \mathrm{m}^{2}$ and $0.5 \mathrm{~cm}$ thick each, is placed between the proppant and sand. The model is saturated with saline water, and heated to the predetermined temperature. The initial water permeability coefficient is determined $\left(K_{0}\right)$, at the temperature of the experiment. At that, for calculating, the length equal to the length of the model filled with sand is applied for the permeability of the model filled with proppant, is much higher than the permeability of the second model half filled with sand, and is not taken into account.

In the next stage a fracturing fluid containing all the additives in the formulation is fed into the model from the side of the proppant pack, at a constant rate.

While injecting the fracturing fluid into the reservoir model the amount of liquid phase exiting the model from the ground sand pack side is determined, and the pressure drop dynamics is observed. Upon reaching a predetermined maximum differential pressure, pumping a fracturing fluid in the model was stopped. At the open outlet valve the pressure drop is determined at which the filtration of a liquid phase through the model filled with ground sand was terminated. Next, exposure of the reservoir model is done at the experiment temperature for the composition destruction.

After exposure, filtering of mineralized water proceeds in the opposite direction up to the differential pressure stabilization, and the final water permeability coefficient $\left(K_{k}\right)$ is determined.

From the initial and final permeability coefficient values the permeability recovery coefficient $\beta=K_{k} / K_{0}$ is calculated.

As a visual illustration, the description and the results of the experiments carried out for comparing the characteristics of two fracturing fluids are shown below. As a base fluid for hydraulic fracturing (experiment no. 1), a water-based fluid most often used at fracturing - cross-linked polysaccharide gel - was applied. As a thickener in the liquid, a gelling agent based on guar gum in a concentration of $3.6 \mathrm{~kg} / \mathrm{m}^{3}$ (30 pounds per 1000 gallons) was used.

For crosslinking of the polysaccharide, a boric crosslinker was used. For the destruction of the liquid in-situ, an oxidizing breaker was injected in the gel composition. The second liquid for reservoir fracturing (experiment no. 2 and no. 3) was an experimental non-guar fracturing fluid based on synthetic high molecular compounds. Prior to filtration tests, operation performance of fracturing liquid were investigated, namely the effective viscosity at the injection/formation temperature, and thermal stability at $75^{\circ} \mathrm{C}$, the time of degradation in-situ, that confirm the possibility of using these systems during hydraulic fracturing. Data on the rheological characteristics of the fracturing fluids are presented in Table 1.

Test experiments were performed at the temperature of $75^{\circ} \mathrm{C}$, and at the predetermined gas permeability in porous medium reservoir.

For experiment no. 1, according to the above technique, a packed reservoir model having the length of $32.8 \mathrm{~cm}$ and the internal section of $4.91 \mathrm{~cm}^{2}$ was prepared. A $18 \mathrm{~cm}$ long part of the model was packed with quartz sand. The rest of the model - with a technological layer of sand and 16/20 proppant fraction produced by the Carbo Ceramics. After saturating

Table 1. Rheological characteristics of fracturing fluids

\begin{tabular}{|l|c|c|c|}
\hline \multicolumn{1}{|c|}{ Parameter } & Unit of \\
\cline { 3 - 4 } & measurement & $\begin{array}{c}\text { Parameter value } \\
\text { fracturing fluid } \\
\text { experiment no. 1 }\end{array}$ & $\begin{array}{c}\text { fracturing fluid } \\
\text { experiment no. 2, 3 }\end{array}$ \\
\hline Fluid effective viscosity, at temperature $25^{\circ} \mathrm{C}$ and shear rate $100 \mathrm{~s}^{-1}$ & $\mathrm{mPa} \cdot \mathrm{s}$ & 1250 & 300 \\
\hline Non-Newtonian behaviour coefficient $n$, at temperature $25^{\circ} \mathrm{C}$ & - & 0.25 & 0.24 \\
\hline Consistency index $K$, at temperature $25^{\circ} \mathrm{C}$ & $\mathrm{Pa} \cdot \mathrm{s}^{\mathrm{n}}$ & 38.95 & 10.13 \\
\hline Fluid effective viscosity, at temperature $75^{\circ} \mathrm{C}$ and shear rate $100 \mathrm{~s}^{-1}$ & $\mathrm{mPa} \cdot \mathrm{s}$ & 1130 & 350 \\
\hline Non-Newtonian behaviour coefficient $n$, at temperature $75^{\circ} \mathrm{C}$ & - & 0.40 & 0.33 \\
\hline Consistency index $K$, at temperature $75^{\circ} \mathrm{C}$ & $\mathrm{Pa} \cdot \mathrm{s}^{\mathrm{n}}$ & 17.69 & 7.71 \\
\hline
\end{tabular}


the model with saline water, its initial water permeability at the temperature of $75^{\circ} \mathrm{C}$ was $0.149 \mu \mathrm{m}^{2}$. Pore volume of the part of the model filled with sand was $V_{p o r}=23.96 \mathrm{~cm}^{3}$.

The injection of the fracturing fluid no. 1 into the watersaturated formation model was performed at a flow rate of $\mathrm{FIR}=200 \mathrm{~cm}^{3} /$ hour. Dynamics of injection showed the presence of a jump in pressure drop $(\Delta \mathrm{P})$ after filling a layer of proppant with gel. In the process of injection, up to a maximum value, filtering is not slowed down. After reaching the maximum value $\Delta \mathrm{P}$ and pumping stop, the filtration almost stopped with reducing $\Delta \mathrm{P}$ to the level of $1.4 \mathrm{MPa}$. The high differential pressure at the termination of filtering indicates both of the presence of a guar gum filter cake, and of increasing the viscosity of the fracturing fluid in the proppant part of the model with the fracture fluid retained for the destruction of fracture liquid. After, water is injected in the model from the side opposite to the previous injection of the fracturing fluid. Water filtration through the model started in the reverse direction at a flow rate $F I R=200 \mathrm{~cm}^{3} /$ hour. The initial stage of the filtration was accompanied by differential pressure rising to $2.7 \mathrm{MPa}$. This pressure differential behavior indicates incomplete guar gum cake destruction with an oxidative destructor. However, during water filtration, it is largely washed out of the model, since the pressure drop began to decline rapidly. Upon reaching the value of $\Delta \mathrm{P}=0.16 \mathrm{MPa}$ the flow rate was reduced to $80 \mathrm{~cm}^{3} /$ hour, and water filtration continued until differential pressure stabilization.

After setting a stable $\Delta P$ value, the final water permeability value, penetration recovery coefficient, $\beta=0.808$, and the efficiency of hydraulic fracturing fluid equalling $63.2 \%$, were determined.

Basic parameters of the reservoir model and the results obtained are shown in Table 2 and Figure 2. The graph reflects the current amount of liquid phase withdrawn from model during injection of fracturing liquid in portions of the pore volume of the model part filled with sand $\left(V_{p o r}\right)$, and the change in differential pressure at various stages of the experiment, depending upon the volume of injection, as well as in portions of the pore volume of the part of the model filled with sand.

For experiment no. 2 with fracturing liquid no. 2, a packed reservoir model similar to the one used in the experiment no. 1, was prepared. After saturating the model with mineralized water, its initial water permeability at the temperature of $75^{\circ} \mathrm{C}$ was $0.150 \mu \mathrm{m}^{2}$. Pore volume of the part of the model filled with sand $-V_{p o r}=25.87 \mathrm{~cm}^{3}$.

Injection of a fracturing fluid no. 2 into the water-saturated formation model was performed at a flow rate of $\mathrm{FlR}=200 \mathrm{~cm}^{3} /$ hour. The dynamics of the injection showed no jump in the differential pressure after filling the proppant layer with the composition. In the injection process, up to the maximum $\Delta P=4.2 \mathrm{MPa}$, filtering, as in the first experiment, is not slowed down. In addition, at the differential pressure, values close to the maximum pressure drop, flattening of the curve was observed, indicating the penetration in porous medium of almost all the injected fluid, and the absence of cake. After reaching the maximum value of $\Delta P$ and stop of pumping, filtering virtually ended at the comparatively low value $\Delta P=0,1 \mathrm{MPa}$, which also indicates the absence of the

Table 2. Results of investigating the permeability recovery coefficient of the packed model after its exposure to fracturing fluids

\begin{tabular}{|c|c|c|c|}
\hline Parameter & $\begin{array}{l}\text { Experiment } \\
\text { no. } 1\end{array}$ & $\begin{array}{l}\text { Experiment } \\
\text { no. } 2\end{array}$ & $\begin{array}{l}\text { Experiment } \\
\text { no. } 3\end{array}$ \\
\hline Type of a fracturing fluid & $\begin{array}{c}\text { Fracturing fluid no. } 1 \\
\text { Cross-linked } \\
\text { polysaccharide gel }\end{array}$ & \multicolumn{2}{|c|}{$\begin{array}{l}\text { Fracturing fluid no. } 2 \\
\text { Guar-free fracturing fluid }\end{array}$} \\
\hline Model length [cm] & 32.8 & 32.6 & 32.9 \\
\hline Model internal section $\left[\mathrm{cm}^{2}\right]$ & 4.91 & 4.91 & 4.91 \\
\hline Proppant layer $[\mathrm{cm}]$ & 13.3 & 13.1 & 13.4 \\
\hline Sand layer $[\mathrm{cm}]$ & 18.0 & 18.0 & 18.0 \\
\hline Model average pore volume $\left[\mathrm{cm}^{3}\right]$ & 46.67 & 46.85 & 42.10 \\
\hline Pore volume of the model part filled with ground sand, $V_{p o r}\left[\mathrm{~cm}^{3}\right]$ & 23.96 & 25.87 & 23.03 \\
\hline Average model porosity [\%] & 28.99 & 29.27 & 26.85 \\
\hline Experiment temperature $\left[{ }^{\circ} \mathrm{C}\right]$ & 75 & 75 & 75 \\
\hline Mineralized water viscosity, at $75^{\circ} \mathrm{C}[\mathrm{mPa} \cdot \mathrm{s}]$ & 0.50 & 0.50 & 0.50 \\
\hline Initial water permeability of model $\left[\mu \mathrm{m}^{2}\right]$ & 0.149 & 0.150 & 0.036 \\
\hline Final water permeability of model $\left[\mu \mathrm{m}^{2}\right]$ & 0.1201 & 0.0587 & 0.021 \\
\hline Permeability recovery coefficient, $\beta$ & 0.808 & 0.392 & 0.588 \\
\hline Fracturing fluid effectiveness [\%] & 63.2 & 29.7 & 26.2 \\
\hline
\end{tabular}


filter cake and deep penetration of fracturing fluid no. 2 into the sandy part of the model.

After exposure of the reservoir model for the degradation process, water filtering through the model started in the reverse direction at a flow rate of FIR $=200 \mathrm{~cm}^{3} /$ hour. Filtering is not accompanied by a pressure drop increase and continued till the stabilization of differential pressure.

After setting a $\Delta P$ stable value, permeability recovery coefficient was defined $\beta=0.392$, and the effectiveness of the fracturing fluid was $29.7 \%$.

Basic parameters of the reservoir model and the results are shown in Table 2 and in Figure 3.
In experiment no. 2, low values of permeability recovery were obtained, which could be due to the deep penetration of the composition of experimental fracturing fluid no. 2 in the part of the model which was sandpacked. In addition, there is extremely low efficiency of the liquid, which involves the use of large injection amounts at the "cushion" stage for creating, opening and widening of the fracture as compared with fracturing liquid no. 1.

Repeated testing of fracturing fluid no. 2 was performed taking into consideration the adjusted parameters (experiment no. 3). The permeability of the part of the model with ground sand was reduced to the level of $0.04 \mu \mathrm{m}^{2}$ and the

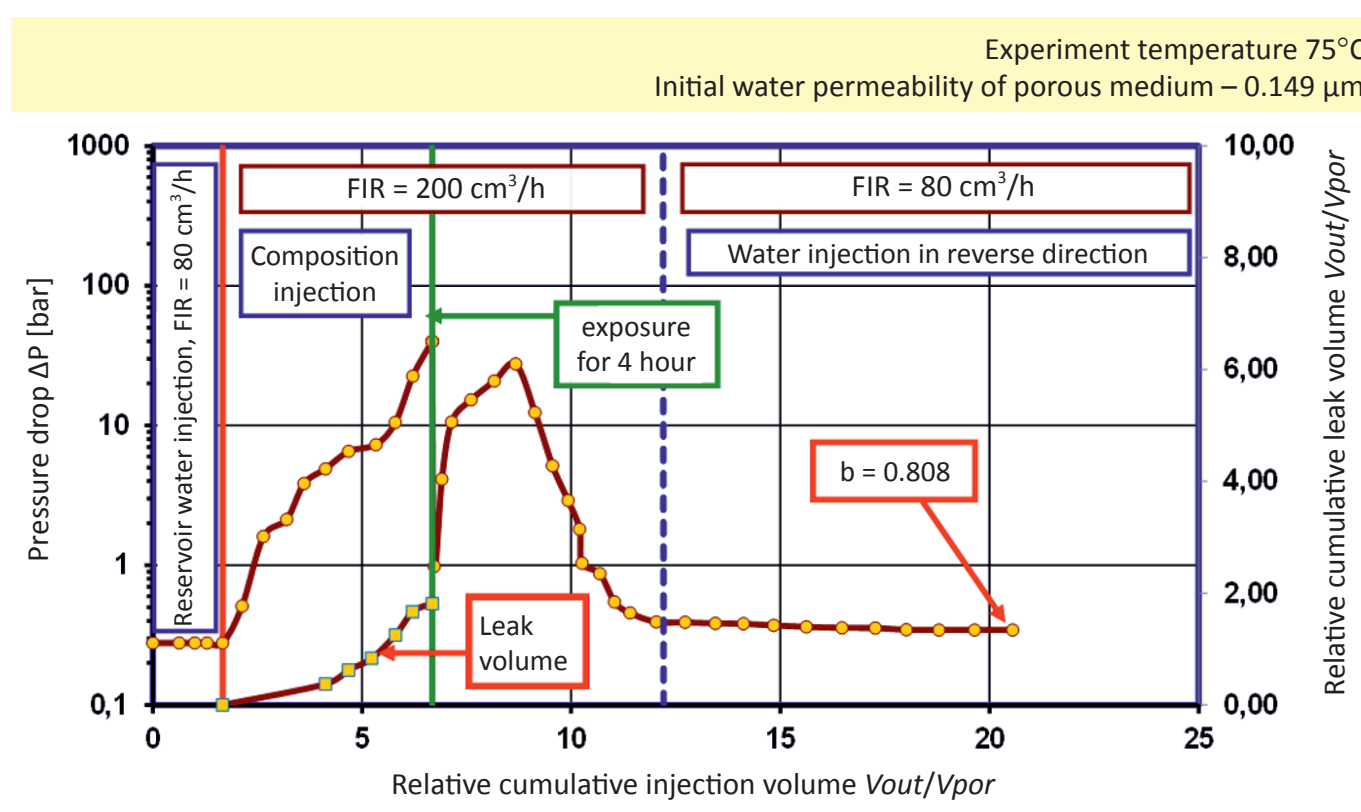

Fig. 2. Dynamics of relative cumulative leak volume and pressure drop at the filtration of fracturing fluid no. 1 through water-saturated reservoir model in experiment no. 1

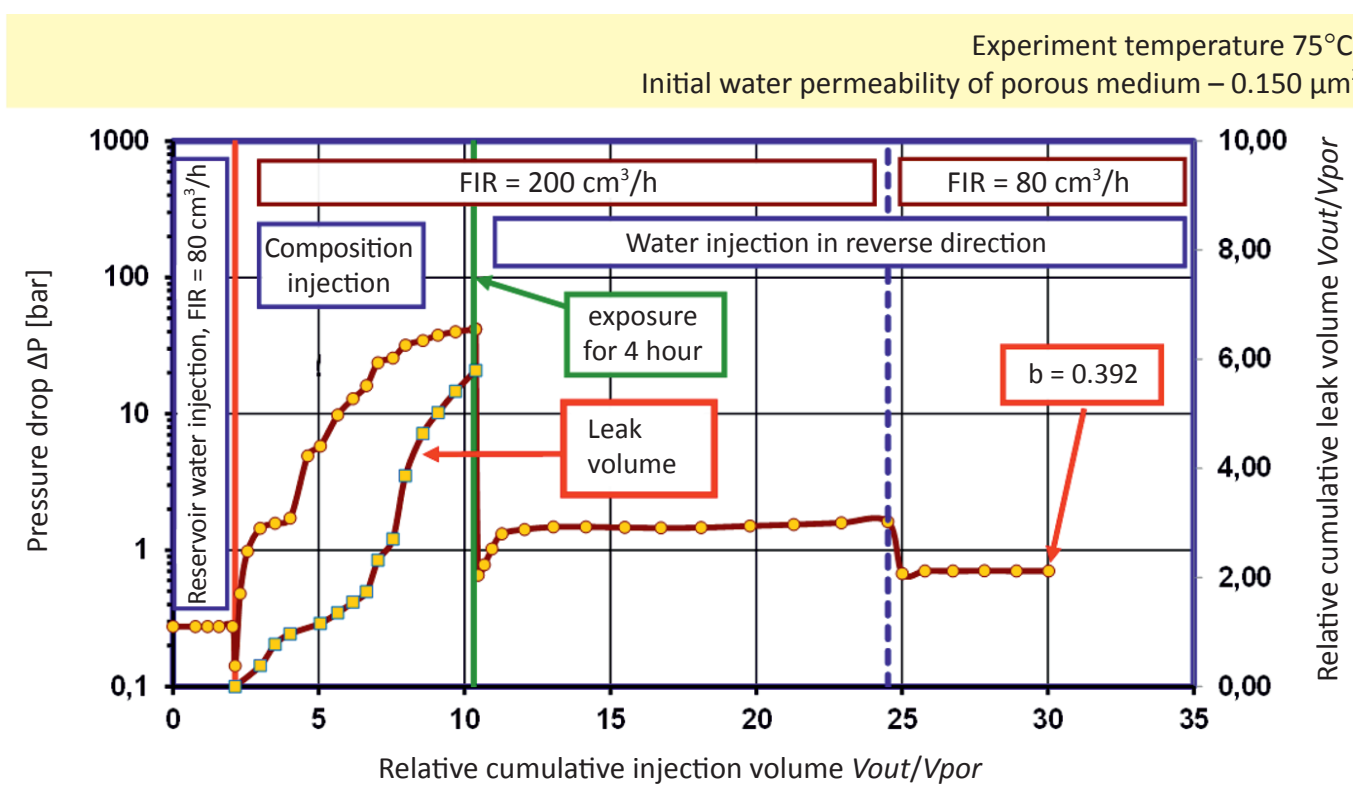

Fig. 3. Dynamics of relative cumulative leak volume and pressure drop at the filtration of fracturing fluid no. 2 through water-saturated reservoir model in experiment no. 2 


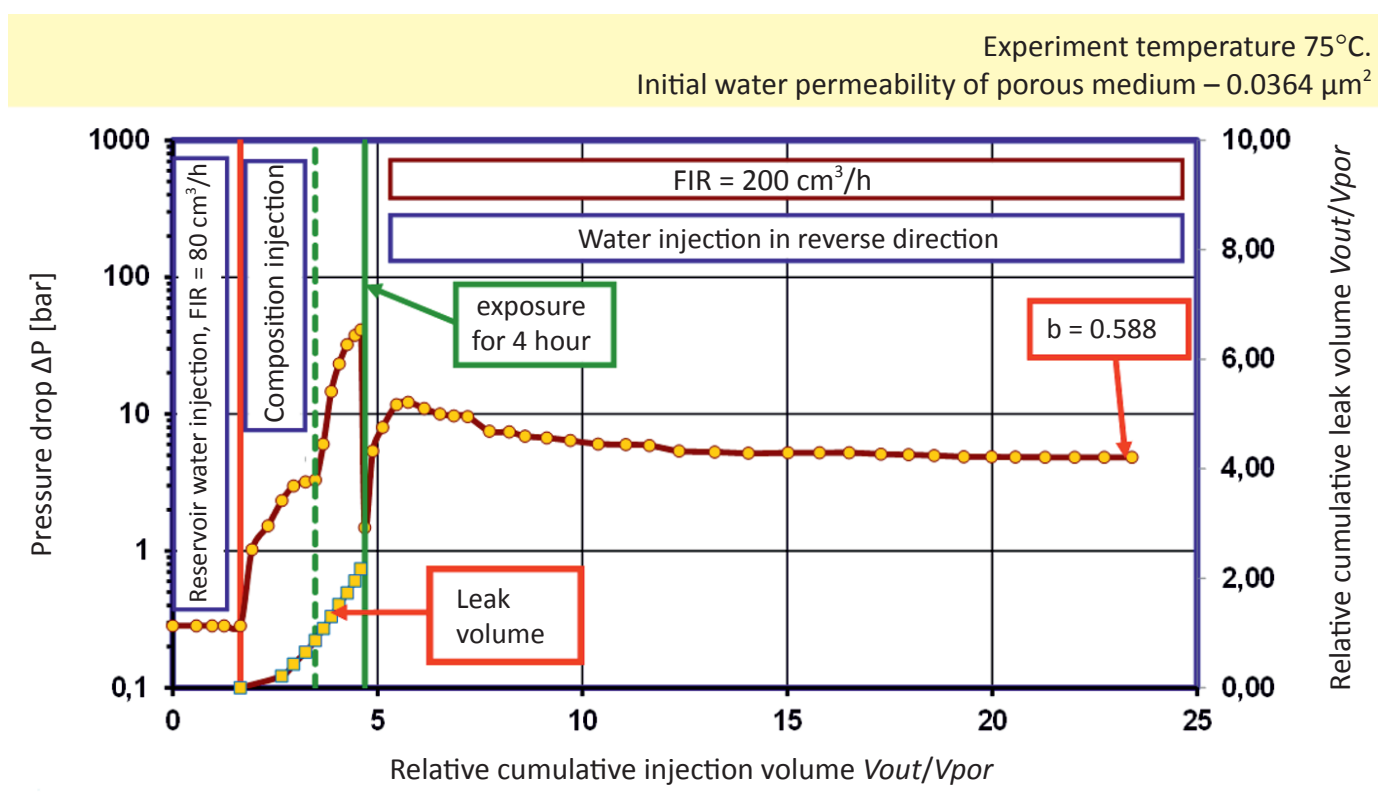

Fig. 4. Dynamics of relative cumulative leak volume and pressure drop at the filtration of fracturing fluid no. 2 through water-saturated reservoir model in experiment no. 3

exposure time of fracturing fluid for the destruction was increased.

Injection of the fluid into the water-saturated reservoir model showed a pronounced jump in the differential pressure after filling the composition with the proppant layer. In the process of injection, up to a maximum value of $\Delta P=4.2 \mathrm{MPa}$, filtering is not slowed down.

After exposure of reservoir model for the composition degradation process, water filtering was started through the model in the reverse direction at a flow rate $\mathrm{FIR}=200 \mathrm{~cm}^{3} /$ hour. After setting a $\Delta P$ stable value, the permeability recovery coefficient was defined $\beta=0.588$. The value of this parameter is higher than that obtained in the experiment no. 2. However, the effectiveness of the fracturing fluid was $26.2 \%$. Conse- quently, in the absence of the insulating cake, the fracturing fluid efficiency remained at the same level as in experiment no. 2 despite the permeability reduction in the part of the model with ground sand. Basic parameters of the reservoir model and the results are shown in Table 2 and in Figure 4.

The material presented shows that by using the express method of testing the fracturing fluids in packed reservoir models, makes it possible for the carrying out of a comparative evaluation of the permeability recovery coefficient and effectiveness of various liquids, as well as evaluating the dependence of these characteristics on the permeability of the porous medium, and optimizing the composition of an individual fracturing fluid for specific geological and physical conditions of the deposit.

Please cite as: Nafta-Gaz 2017, no. 4, pp. 236-241, DOI: 10.18668/NG.2017.04.03

Article contributed to the Editor 10.11.2016. Approved for publication 02.01.2017.

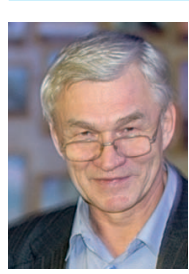

Vladimir B. GUBANOV PhD.

Leading researcher

Gubkin Russian State University of Oil and Gas

(National Research University)

Leninski Prospect 65

Moscow, Russian Federation

E-mail: Gubanowww@gmail.com

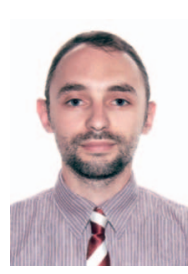

Denis N. MALKIN

Head of chemistry and materials sector for hydraulic fracture

Gubkin Russian State University of Oil and Gas

(National Research University)

Leninski Prospect 65

Moscow, Russian Federation

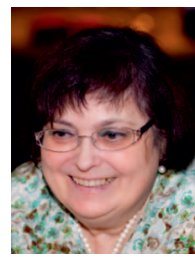

Lubov A. MAGADOVA

Head of "Oilfield Chemistry" Experimental

Researching and Education Centre

Gubkin Russian State University of Oil and Gas

(National Research University)

Leninski Prospect 65

Moscow, Russian Federation 